\title{
Genetic Variability of Hepatitis B and C Viruses in Brazilian Patients With and Without Hepatocellular Carcinoma
}

\author{
Oscar C. Araujo, ${ }^{1}$ José J.F. Barros, ${ }^{1}$ Kycia M. do Ó, ${ }^{2}$ Letícia C. Nabuco, ${ }^{2}$ Charles A. Luz, ${ }^{2}$ \\ Renata M. Perez, ${ }^{2}$ Christian Niel, ${ }^{1}$ Cristiane A. Villela-Nogueira, ${ }^{2}$ and Natalia M. Araujo ${ }^{1 *}$ \\ ${ }^{1}$ Laboratory of Molecular Virology, Oswaldo Cruz Institute, Fiocruz, Rio de Janeiro, Brazil \\ ${ }^{2}$ Hepatology Division, Clementino Fraga Filho University Hospital, Federal University of Rio de Janeiro, \\ Rio de Janeiro, Brazil
}

Most cases of hepatocellular carcinoma (HCC) are due to chronic hepatitis B virus (HBV) or hepatitis $C$ virus (HCV) infection worldwide. The aim of this study was to determine the viral genotypes and frequency of 17 mutations (15 for HBV and 2 for HCV), described previously as able to influence the course of chronic liver disease, in patients with and without HCC. This transversal study included 157 Brazilian patients with chronic hepatitis $B(n=51)$ and $C$ $(n=106)$. Of these, 12 and 40 patients had $\mathrm{HBV}$ - and HCV-related HCC, respectively. Nucleotide sequencing of core promoter, precore, and pre-S/S regions of HBV and core region of HCV strains was performed to determine their genotypes and the frequency of the respective mutations. Among the HBV isolates, subgenotype $A 1$ was the most prevalent in both patients with $(90 \%)$ and without $(61 \%)$ HCC. Fourteen out of the 15 mutations under study, as well as five different pre-S deletions, were identified. Core promoter T1753V, A1762T, and G1764A mutations were more frequent in patients with HCC than in those without, although with no statistical difference. However, a significant correlation was observed between T1753V mutation and elevation of transaminases levels $(P<0.05)$. As for HCV, mutation at residue 70 in the core protein of genotype 1b strains was significantly more frequent in patients with cirrhosis $(56.3 \%)$ than in those without $(9.1 \%)(P=0.018)$. The detection of some key mutations in the genomes of $\mathrm{HBV}$ and HCV might be helpful to predict the clinical outcome of patients with chronic liver disease. J. Med. Virol. 86:217-223, 2014. (C) 2013 Wiley Periodicals, Inc.

KEY WORDS: HBV; HCV; mutations; cirrhosis; hepatocellular carcinoma

\section{INTRODUCTION}

Hepatocellular carcinoma (HCC) is a leading cause of cancer-related death worldwide, and the burden of this cancer is expected to increase further in coming years [Ferlay et al., 2008; Venook et al., 2010]. Up to $80 \%$ of HCC cases are associated with chronic hepatitis $\mathrm{B}$ virus (HBV) or hepatitis $\mathrm{C}$ virus (HCV) infection [Perz et al., 2006]. However, the precise pathogenetic mechanisms linking viral infection and HCC remain obscure.

Some virus genotypes and genetic mutations have been suggested to contribute to the severity of liver disease and increased risk of HCC [Tsai and Chung, 2010; El-Serag, 2012; Arzumanyan et al., 2013]. In a specific manner, HBV genotypes A1 [Kew et al., 2005], C [Kao et al., 2002; Chan et al., 2004; Chen et al., 2004] and F [Livingston et al., 2007], as well as HCV genotypes 1b [Bruno et al., 2007; Raimondi et al., 2009], and 3a [Idrees et al., 2009] have been found to be associated with higher rates of HCC development.

Nucleotide substitutions in the HBV core promoter (nts 1613-1849), resulting in a decreased expression of $\mathrm{HBeAg}$ but enhanced viral replication, as well as deletions in the pre-S region (leading to truncated pre-S/S proteins), have been associated with the progression of liver disease and HCC [Asim et al., 2010; Tsai and Chung, 2010; Kao et al., 2012; Kitab et al., 2012; $\mathrm{Qu}$ et al., 2013]. On the other side, the G1896A mutation in the pre-core region (nts

Grant sponsor: Fundação Carlos Chagas Filho de Amparo à Pesquisa do Estado do Rio de Janeiro (FAPERJ)

${ }^{*}$ Correspondence to: Natalia M. Araujo, Laboratory of Molecular Virology, Oswaldo Cruz Institute, FIOCRUZ, Av. Brasil 4365, 21040-360 Rio de Janeiro, RJ, Brazil.

E-mail: nmaraujo@ioc.fiocruz.br

Accepted 9 October 2013

DOI 10.1002/jmv.23837

Published online 6 November 2013 in Wiley Online Library (wileyonlinelibrary.com). 
1814-1900) of the HBV genome, which creates a premature stop codon, abolishing the production of $\mathrm{HBeAg}$, has been associated with a decreased incidence of HCC [Liu et al., 2006; Yang et al., 2008].

HCV core protein alters host gene expression and binds to several tumor suppressor proteins [Tsai and Chung, 2010]. Several clinical studies, especially in Japanese populations, have revealed that mutations at core codons 70 and 91 of the HCV genotype $1 b$ isolates were associated with HCC [Akuta et al., 2007; Kobayashi et al., 2010; Nakamoto et al., 2010]. However, other investigators did not find such an association for the mutation at position 91 [Fishman et al., 2009; El-Shamy et al., 2013].

In Brazil, approximately 9,000 new cases of HCC (2.9\% of all cancers) are registered each year, and $5 \%$ of the cancer-related deaths are attributed to HCC [Ferlay et al., 2008]. However, no report has been published so far on the viral factors associated to HCC in Brazilian patients.

In this study, the viral genotypes and the presence of mutations in the core promoter, pre-core, and pre$\mathrm{S}$ regions of $\mathrm{HBV}$ isolates, and in the core region of HCV strains, were investigated, and their frequencies compared in patients with and without HCC.

\section{PATIENTS AND METHODS}

\section{Patients}

The study included 51 HBsAg positive patients (12 with HCC and 39 with chronic liver disease but without HCC) and 106 HCV RNA positive patients (40 with HCC and 66 with chronic liver disease but without HCC) referred to the Clementino Fraga Filho University Hospital (HUCFF), Rio de Janeiro, Brazil, from April 2010 to March 2013. Demographic, laboratory, and clinical information, including age, gender, HBV serological status, liver function tests, and antiviral treatment were abstracted from the medical records of participants. HCV carriers without HCC were classified further into two groups, with and without cirrhosis. The diagnosis of liver cirrhosis was made by liver biopsy or by the presence of clinical and laboratory features of portal hypertension at ultrasound or upper endoscopy. HCC diagnosis was based on elevated serum alpha-fetoprotein level ( $>400 \mathrm{ng} / \mathrm{ml}$ ) combined with at least one positive image on the angiography, ultrasonography, and/or computed tomography. Patients with normal levels of alpha-fetoprotein should have two image methods showing positive results for the diagnosis of HCC. The hospital's Ethics Committee approved the study protocol and an informed consent form was obtained from all patients.

\section{Nucleic Acids Extraction and Amplification}

HBV DNA and HCV RNA were extracted from $0.2 \mathrm{ml}$ of serum by using High Pure Viral Nucleic
Acid kit (Roche Diagnostics, Mannheim, Germany) and resuspended in $50 \mu \mathrm{l}$ of nuclease free water.

HBV pre-S/S region was amplified by semi-nested polymerase chain reaction (PCR). The first round of amplification was performed with $4 \mu \mathrm{l}$ of DNA, $1 \mathrm{U}$ of Taq DNA polymerase (Invitrogen, Carlsbad, CA), and sense PS1 (5'-CCATATTCTTGGGAACAAGA- $3^{\prime}$, nts 2826-2845) and antisense P3 (5'-AAAGCCCAAAAGACCCACAA-3', nts 1000-1019) oligonucleotide primers. Second round PCR was performed with $2 \mu$ l of the first round product, $1 \mathrm{U}$ of Taq DNA polymerase (Invitrogen), sense PS1, and antisense S2 (5'-GGGTT TAAATGTATACCCAAAGA-3', nts 819-841) primers. Both rounds were performed in the same conditions, that is, $94^{\circ} \mathrm{C}$ for $3 \mathrm{~min}, 35$ cycles at $95^{\circ} \mathrm{C}$ for $30 \mathrm{sec}$, $52^{\circ} \mathrm{C}$ for $40 \mathrm{sec}$, and $72^{\circ} \mathrm{C}$ for $2 \mathrm{~min}$, followed by a final elongation at $72^{\circ} \mathrm{C}$ for $7 \mathrm{~min}$. Core promoter and pre$\mathrm{C}$ regions were amplified in a nested PCR assay carried out with $4 \mu \mathrm{l}$ of DNA, $1 \mathrm{U}$ of Taq DNA polymerase (Invitrogen), sense X1 (5'-ACCTCCTTTCCATGGCTGCT-3', nts 1363-1382), and antisense C2 (5'-CTAACATTGAGATTCCCGAGATTGAGA-3', nts 2432-2458) primers. The second round of amplification was performed using $2 \mu \mathrm{l}$ of the first round PCR product, $1 \mathrm{U}$ of Taq DNA polymerase (Invitrogen), sense X4 (5'-AAGGTCTTACATAAGAGGAC-3', nts 1644-1663), and antisense C3 (5'TTGCCTGAGTGCAGTATGGT- ${ }^{\prime}{ }^{\prime}$, nts 2056-2075) primers. PCR conditions for both rounds were $94^{\circ} \mathrm{C}$ for $2 \mathrm{~min}, 35$ cycles at $94^{\circ} \mathrm{C}$ for $30 \mathrm{sec}, 52^{\circ} \mathrm{C}$ for $30 \mathrm{sec}$, and $72^{\circ} \mathrm{C}$ for $1 \mathrm{~min} 30 \mathrm{sec}$, followed by a final elongation at $72^{\circ} \mathrm{C}$ for $7 \mathrm{~min}$.

The HCV core region was amplified by reverse transcription (RT)-PCR. RT and the first round of PCR were performed in a single tube using the SuperScript III One-Step RT-PCR System with Platinum Taq kit (Invitrogen), $4 \mu \mathrm{l}$ of RNA, and outer primers Sc2 and Ac2 [Ohno et al., 1997]. RT step was for $45^{\circ} \mathrm{C}$ for $30 \mathrm{~min}$, and was followed by DNA denaturation at $94^{\circ} \mathrm{C}$ for $2 \mathrm{~min}, 20 \mathrm{PCR}$ cycles at $94^{\circ} \mathrm{C}$ for $1 \mathrm{~min}, 45^{\circ} \mathrm{C}$ for $1 \mathrm{~min}$, and $68^{\circ} \mathrm{C}$ for $1 \mathrm{~min}$, and 20 additional cycles at $94^{\circ} \mathrm{C}$ for $1 \mathrm{~min}, 60^{\circ} \mathrm{C}$ for $1 \mathrm{~min}$, and $68^{\circ} \mathrm{C}$ for $1 \mathrm{~min}$, and a final elongation at $68^{\circ} \mathrm{C}$ for $5 \mathrm{~min}$. Second round PCR was carried out using $2 \mu \mathrm{l}$ of the first round PCR product, $1 \mathrm{U}$ of Taq DNA polymerase (Invitrogen), and inner primers S7 and A5 [Ohno et al., 1997], under the following conditions: $94^{\circ} \mathrm{C}$ for $2 \mathrm{~min} ; 30$ cycles at $94^{\circ} \mathrm{C}$ for $1 \mathrm{~min}$, $62^{\circ} \mathrm{C}$ for $1 \mathrm{~min}$, and $72^{\circ} \mathrm{C}$ for $1 \mathrm{~min}$, with a final extension step at $72^{\circ} \mathrm{C}$ for $7 \mathrm{~min}$.

\section{Direct Nucleotide Sequencing and Genotyping}

PCR products were purified using the Wizard SV Gel and PCR Clean-Up System (Promega, Madison, WI) and bidirectionally sequenced using BigDye Terminator kit (Life Technologies, Carlsbad, CA). Sequencing reactions were analyzed on an ABI3730 automated sequencer (Life Technologies). HBV and HCV genotypes were determined by direct sequencing 
of the pre-S/S and core amplicons, respectively, followed by phylogenetic analysis using MEGA software version 5.1 [Tamura et al., 2011].

\section{Statistical Analysis}

Statistical analyses were performed using Pearson chi-square test and Fisher's exact test for categorical variables, and Mann-Whitney's $U$-test or independent samples $t$-test for quantitative variables, as appropriate. Differences were considered significant for $P$ values less than 0.05 . The software used was the statistical analysis SPSS software, version 18.0.

\section{RESULTS}

\section{Characteristics of Patients Infected With HBV and HCV}

Demographic, biochemical, and serological characteristics of the $51 \mathrm{HBV}$ chronic carriers of this study are shown in Table I. The mean age of patients with HCC was significantly higher than in patients without HCC (58.8 \pm 10.3 vs. $40.4 \pm 16.4$ years, $P<0.001)$. A major proportion of male was observed in the HCC group $(83.3 \%$ vs. $66.7 \%)$. Also, HCC group had significantly higher aspartate aminotransferase (AST), alkaline phosphatase (ALP), gamma-glutamyl transpeptidade (GGT), and total bilirubin (T.BIL) levels, as well as lower serum albumin (ALB) values than the group without HCC $(P<0.05)$. HBeAg positivity was observed in $2 / 12(16.7 \%)$ patients with HCC and 14/39 (35.9\%) patients without HCC. Fifty percent of the patients with HCC were under antiviral treatment, compared to $25.6 \%$ of those without HCC.

TABLE I. Baseline Characteristics of HBV Infected Patients

\begin{tabular}{|c|c|c|c|}
\hline Characteristics & $\begin{array}{c}\mathrm{HCC} \\
(\mathrm{n}=12)\end{array}$ & $\begin{array}{c}\text { Without } \\
\text { HCC }(n=39)\end{array}$ & $P$-Value \\
\hline $\begin{array}{l}\text { Age } \\
\quad(\text { years, mean } \pm \mathrm{SD})\end{array}$ & $58.8 \pm 10.3$ & $40.4 \pm 16.4$ & $<0.001$ \\
\hline Male $(\%)$ & $10(83.3 \%)$ & $26(66.7 \%)$ & NS \\
\hline $\begin{array}{l}\mathrm{ALT} \\
\quad(\mathrm{U} / \mathrm{L}, \text { mean } \pm \mathrm{SD})\end{array}$ & $53.2 \pm 30.0$ & $54.3 \pm 42.7$ & NS \\
\hline $\begin{array}{l}\mathrm{AST} \\
(\mathrm{U} / \mathrm{L}, \text { mean } \pm \mathrm{SD})\end{array}$ & $84.3 \pm 74.5$ & $42.9 \pm 30.0$ & 0.006 \\
\hline $\begin{array}{l}\mathrm{ALP} \\
\quad(\mathrm{U} / \mathrm{L}, \text { mean } \pm \mathrm{SD})\end{array}$ & $261.3 \pm 273.6$ & $99.6 \pm 78.7$ & 0.003 \\
\hline $\begin{array}{l}\mathrm{GGT} \\
\quad(\mathrm{U} / \mathrm{L}, \text { mean } \pm \mathrm{SD})\end{array}$ & $167.3 \pm 139.4$ & $57.5 \pm 34.6$ & 0.012 \\
\hline $\mathrm{ALB}(\mathrm{g} / \mathrm{dl}$, mean $\pm \mathrm{SD})$ & $3.5 \pm 0.8$ & $4.2 \pm 0.6$ & 0.010 \\
\hline $\begin{array}{l}\text { T.BIL } \\
\quad(\mathrm{mg} / \mathrm{dl}, \text { mean } \pm \mathrm{SD})\end{array}$ & $1.7 \pm 1.4$ & $0.5 \pm 0.3$ & $<0.001$ \\
\hline HBeAg positive (\%) & $2(16.7 \%)$ & $14(35.9 \%)$ & NS \\
\hline $\begin{array}{l}\text { Antiviral } \\
\quad \text { treatment }(\%)\end{array}$ & $6(50.0 \%)$ & $10(25.6 \%)$ & - \\
\hline
\end{tabular}

HCC, hepatocellular carcinoma; SD, standard deviation; ALT, alanine aminotransferase; AST, aspartate aminotransferase; ALP, alkaline phosphatase; GGT, gamma-glutamyl transpeptidase; ALB, serum albumin; T.BIL, total bilirubin; NS, not significant.
Table II shows the demographic and biochemical characteristics of the $106 \mathrm{HCV}$ infected patients, classified in HCC and without HCC carriers. The group of patients without HCC was divided further into cirrhosis and without cirrhosis subgroups. The mean age of the HCC patients was significantly higher than those with $(P=0.047)$ and without cirrhosis $(P=0.002)$. The group without cirrhosis had a lower proportion of male compared to the HCC $(P=0.008)$ and cirrhosis $(P=0.011)$ groups, respectively. No statistically significant difference was observed between HCC and cirrhosis groups in relation to ALT, AST, ALP, GGT, ALB, and T.BIL levels. However, the group without cirrhosis had significantly higher ALB values and lower ALT, AST, ALP, GGT, and T.BIL levels $(P<0.05$ for all observations) than the other two groups.

\section{Genotypes Distribution of and Key Mutations in the HBV Isolates}

The distribution of HBV genotypes/subgenotypes and the occurrence of various mutations in the core promoter (including upper regulatory region and basal core promoter) and pre-core regions of the HBV isolates are shown in Table III. Subgenotype A1 was the most frequent in both HCC and without HCC groups, being found in 9 out of 10 patients with HCC. In the upper regulatory region of the core promoter, T1636R and C1637W were only found in patients without HCC, whereas C1653T was found in both HCC and without HCC groups. Substitutions T1753V, A1757G, A1762T, G1764A, C1766K, and $\mathrm{T} 1768 \mathrm{~A}$, in the basal core promoter, were also detected in both groups. A1762T was present in association with $\mathrm{G} 1764 \mathrm{~A}$ in $50.0 \%$ and $33.3 \%$ of patients with and without HCC, respectively. None of the five pre-core mutations under study was present in patients with HCC. However, substitutions A1814Y, T1815M, G1896A, and G1899A were found in $3-15 \%$ of the patients without HCC. The combination (i) double mutant at nts 1762 and 1764 and (ii) wild-type at nt 1896 was found in isolates infecting both patients with and without HCC, although with a higher frequency among HCC patients $(50.0 \%$ vs. $25.9 \%)$.

The presence of pre-S deletions in the HBV genome was observed in 1/8 (12.5\%) and 4/34 (11.8\%) patients with and without HCC, respectively. Four deletions occurred in the pre-S2 region and one in the pre-S1 region. Their length was always a multiple of 3 nucleotides, and varied from 6 to 72 nucleotides (Table IV).

\section{Genotypes Distribution of the HCV Isolates and Mutations in the Core Protein}

Table V shows the genotypes distribution of the $106 \mathrm{HCV}$ isolates of this study, as well as the frequency of mutations in the core protein at residues 70 (R70Q) and 91 (L91M) (only genotype 1b isolates 


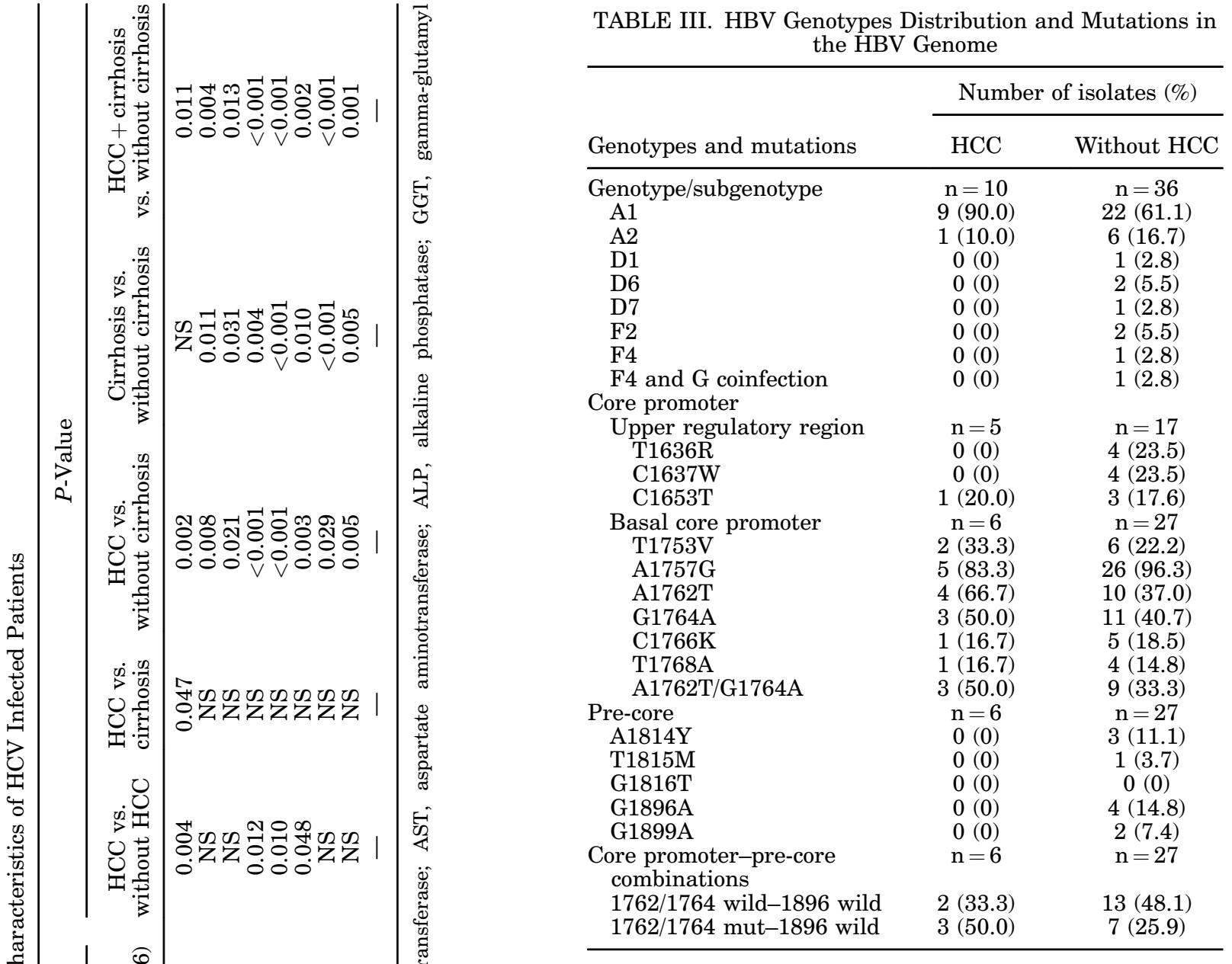

for L91M). Genotypes 1a, 1b, and 3a were the only ones found. In all three groups of patients (HCC, cirrhosis and without cirrhosis), genotypes 1a (34$50 \%)$ and $1 \mathrm{~b}(35-42 \%)$ were more frequent than $3 \mathrm{a}$ (10-23\%). Amongst patients infected with HCV genotype $1 \mathrm{~b}$, the mutation R70Q was significantly more frequent in patients with cirrhosis than in those without (56.3\% vs. $9.1 \%, P=0.018$ ) and in HCC plus cirrhosis groups than without cirrhosis group (50.0\% vs. $9.1 \%, P=0.028$ ). However, no significant association was observed for mutation L91M, for which similar frequencies were obtained in the three groups of patients.

\section{Association Between HBV T1753V Mutation and Age and Transaminases Levels of the Patients}

Table VI shows the mean age and transaminases levels of the HBV infected patients and their association with the presence of determined mutations on the viral genome. Patients infected with a virus isolate (i) from subgenotype A1, (ii) showing a deletion in the pre-S region, or (iii) with one of the mutations C1653T, T1753V, A1762T, or G1764A, had higher mean levels of ALT and AST than the others. However, this difference of transaminase levels was 
TABLE IV. Deletions in the Pre-S Region of HBV Isolates

\begin{tabular}{|c|c|c|c|c|c|}
\hline \multicolumn{2}{|c|}{ Patient } & \multicolumn{4}{|c|}{ HBV isolate } \\
\hline Liver disease & Sex/age (years) & Subgenotype & Region & Length (bp) & Segment $(n t)^{a}$ \\
\hline $\mathrm{HCC}$ & $\mathrm{M} / 63$ & A1 & Pre-S2 & 48 & $378-425$ \\
\hline Without HCC & $\mathrm{F} / 63$ & A1 & Pre-S2 & 6 & $417-422$ \\
\hline Without HCC & $\mathrm{M} / 39$ & $\mathrm{~A} 1$ & Pre-S2 & 51 & $370-420$ \\
\hline Without HCC & $\mathrm{M} / 29$ & $\mathrm{~A} 2$ & Pre-S2 & 6 & $421-426$ \\
\hline Without HCC & $\mathrm{M} / 29$ & D6 & Pre-S1 & 72 & $197-268$ \\
\hline
\end{tabular}

${ }^{a}$ Numbering starts from the initiation codon of pre-S1 region and is based on a genotype A isolate (complete genome $=3,221 \mathrm{bp}$ ).

only statistically significant $(P<0.05)$ in the case of the T1753V mutation. In addition, patients infected with $\mathrm{HBV}$ mutated at nt 1753 were significantly older than the others $(P=0.002)$.

In a similar manner, data related to mean age and transaminases levels of the HCV infected patients were computed in an attempt to correlate them with virus genotype and presence of $\mathrm{R} 70 \mathrm{Q}$ and $\mathrm{L} 91 \mathrm{M}$ mutations. However, no association was observed between these parameters (not shown).

\section{DISCUSSION}

A recent Brazilian national survey has shown that HBV and HCV infections accounted for $16 \%$ and $54 \%$ of the cases of HCC, respectively [Carrilho et al., 2010]. The goal of this study was to assess the genotype distributions of the HBV and HCV isolates infecting Brazilian patients with and without HCC as well as to evaluate possible relationships between viral mutations and severity of liver disease. HBV strains from subgenotypes A1, A2, D1, D6, D7, F2, and F4 were detected. Overall frequencies of genotypes $\mathrm{A}, \mathrm{D}$, and $\mathrm{F}$ were $84.4 \%, 8.8 \%$, and $6.7 \%$, respectively, in accordance to previous phylogenetic studies showing that genotypes $\mathrm{A}, \mathrm{D}$, and $\mathrm{F}$ were the most prevalent in Brazil [Araujo et al., 2004; Mello et al., 2007; Motta-Castro et al., 2008]. One case of coinfection with $\mathrm{HBV}$ isolates from genotypes $\mathrm{F} 4$ and
G was detected (in a patient without HCC), and complete nucleotide sequences of the two genotypes were published elsewhere [Araujo et al., 2013]. Nine out of 10 of the isolates infecting HBV-related HCC patients were from subgenotype A1 (Table III). It is noteworthy that subgenotype A1 has been associated with very high rates of HCC in sub-Saharan Africa [Kramvis et al., 1998; Kew et al., 2005]. A casecontrol study of HBsAg-positive African patients has found a 4.5-fold increased risk of HCC in those infected with subgenotype A1 versus other genotypes [Kew et al., 2005]. Conversely, the rate of complications, including HCC, in patients infected with subgenotype A2 has been shown to be lower than in those infected with genotypes C, D, or F1 [SanchezTapias et al., 2002; Livingston et al., 2007].

A number of point mutations in the HBV core promoter and pre-core regions, including T1636R, C1637W, C1653T, T1753V, A1757G, A1762T, G1764A, C1766K, T1768A, A1814Y, T1815M, G1816T, G1896A, and G1899A, as well as in-phase deletions in the pre-S region, have become increasingly recognized to be associated with severe clinical outcome and HCC development [Asim et al., 2010; Tsai and Chung, 2010; Kao et al., 2012; Qu et al., 2013]. All of these mutations, with the exception of G1816T, were detected in this study. Although some mutations were more frequent among patients with HCC than in the others, the differences were not statistically significant.

TABLE V. Genotypes Distribution of the HCV Isolates and Mutations in the Core Protein

\begin{tabular}{|c|c|c|c|c|}
\hline \multirow[b]{2}{*}{ Genotypes and mutations } & \multirow[b]{2}{*}{$\mathrm{HCC}(\mathrm{n}=40)$} & \multicolumn{2}{|c|}{ Without HCC } & \multirow[b]{2}{*}{$P$-Value } \\
\hline & & Cirrhosis $(n=40)$ & Without cirrhosis $(\mathrm{n}=26)$ & \\
\hline \multicolumn{5}{|l|}{ Genotype } \\
\hline $1 \mathrm{a}$ & $17(42.5 \%)$ & $20(50.0)$ & $9(34.6)$ & NS \\
\hline $1 b$ & $14(35.0 \%)$ & $16(40.0)$ & $11(42.3)$ & NS \\
\hline $3 a$ & $9(22.5 \%)$ & $4(10.0)$ & $6(23.1)$ & NS \\
\hline \multicolumn{5}{|l|}{ Mutation R70Q } \\
\hline $1 \mathrm{a}$ & $2 / 17(11.8 \%)$ & $0 / 20(0 \%)$ & 1/9 (11.1\%) & NS \\
\hline $1 \mathrm{~b}$ & $6 / 14(42.9 \%)$ & $9 / 16(56.3 \%)$ & $1 / 11(9.1 \%)$ & $<0.05^{\mathrm{a}}$ \\
\hline $3 a$ & $2 / 9(22.2 \%)$ & $0 / 4(0 \%)$ & $2 / 6(33.3 \%)$ & NS \\
\hline \multicolumn{5}{|l|}{ Mutation L91M } \\
\hline $1 \mathrm{~b}$ & $11 / 14(78.6 \%)$ & $12 / 16(75.0 \%)$ & $8 / 11(72.7 \%)$ & NS \\
\hline
\end{tabular}

${ }^{a}$ Significant $P$ values were obtained when comparing cirrhosis versus without cirrhosis $(P=0.018)$ and HCC + cirrhosis versus without cirrhosis $(P=0.028)$ groups of patients. Other comparisons gave no significant results (NS). 
TABLE VI. Mean Age and Transaminase Levels of the HBV Infected Patients According to Virus Genotypes and Particular Mutations

\begin{tabular}{|c|c|c|c|c|c|c|}
\hline \multirow[b]{2}{*}{ Genotypes/mutations } & \multicolumn{2}{|c|}{ Age (years) } & \multicolumn{2}{|c|}{$\operatorname{ALT}(\mathrm{U} / \mathrm{L})$} & \multicolumn{2}{|c|}{ AST (U/L) } \\
\hline & Mean \pm SD & $P$-Value & Mean \pm SD & $P$-Value & Mean \pm SD & $P$-Value \\
\hline \multicolumn{7}{|l|}{ Subgenotype } \\
\hline A1 & $45.6 \pm 16.6$ & NS & $49.1 \pm 30.5$ & NS & $54.3 \pm 57.5$ & NS \\
\hline A2 & $42.1 \pm 16.7$ & & $28.2 \pm 14.8$ & & $36.0 \pm 21.9$ & \\
\hline \multicolumn{7}{|l|}{ Pre-S deletion } \\
\hline Presence & $44.6 \pm 17.3$ & NS & $87.1 \pm 60.7$ & $\mathrm{NS}$ & $61.6 \pm 50.0$ & NS \\
\hline Absence & $43.7 \pm 15.8$ & & $48.6 \pm 35.2$ & & $52.1 \pm 53.0$ & \\
\hline \multicolumn{7}{|l|}{$\mathrm{C} 1653 \mathrm{~T}$} \\
\hline Presence & $47.0 \pm 15.7$ & NS & $71.9 \pm 51.0$ & NS & $80.0 \pm 51.1$ & NS \\
\hline Absence & $49.3 \pm 16.2$ & & $60.7 \pm 39.5$ & & $68.5 \pm 74.7$ & \\
\hline \multicolumn{7}{|l|}{$\mathrm{T} 1753 \mathrm{~V}$} \\
\hline Presence & $56.6 \pm 13.2$ & 0.002 & $73.5 \pm 39.8$ & 0.036 & $91.4 \pm 75.7$ & 0.005 \\
\hline Absence & $37.3 \pm 16.3$ & & $46.3 \pm 37.1$ & & $39.6 \pm 27.5$ & \\
\hline \multicolumn{7}{|l|}{$\mathrm{A} 1762 \mathrm{~T}$} \\
\hline Presence & $46.0 \pm 18.3$ & NS & $65.1 \pm 39.0$ & NS & $68.1 \pm 37.1$ & NS \\
\hline Absence & $43.2 \pm 17.5$ & & $50.6 \pm 40.3$ & & $45.3 \pm 29.5$ & \\
\hline \multicolumn{7}{|l|}{ G1764A } \\
\hline Presence & $44.2 \pm 16.7$ & NS & $58.3 \pm 38.3$ & NS & $62.5 \pm 36.6$ & NS \\
\hline Absence & $44.3 \pm 18.8$ & & $54.3 \pm 42.0$ & & $46.9 \pm 30.7$ & \\
\hline \multicolumn{7}{|l|}{ G1896A } \\
\hline Presence & $44.0 \pm 12.5$ & NS & $55.7 \pm 53.1$ & NS & $48.0 \pm 40.7$ & NS \\
\hline Absence & $44.9 \pm 18.2$ & & $56.6 \pm 38.6$ & & $65.1 \pm 60.0$ & \\
\hline
\end{tabular}

ALT, alanine aminotransferase; AST, aspartate aminotransferase; SD, standard deviation; NS, not significant.

However, a significant association was observed between mutation T1753V and elevation of ALT and AST levels (Table VI). Such an association has also been found in Moroccan HBV chronic carriers [Kitab et al., 2012].

All the HCV isolates infecting patients of this study were from genotypes $1 \mathrm{a}(43.0 \%), 1 \mathrm{~b}(38.7 \%)$, or $3 \mathrm{a}$ (17.9\%). Such a genotype distribution was consistent with previous studies performed with Brazilian samples describing frequencies of $64-87 \%, 2-5 \%, 13-30 \%$, $<1 \%$, and $<1 \%$ for genotypes $1-5$, respectively [Martins et al., 1998; Oliveira et al., 1999; de Almeida et al., 2004; Campiotto et al., 2005].

The relative risk for HCC has been estimated to be 2.5-fold higher among patients infected with HCV genotype $1 \mathrm{~b}$ than with other genotypes [Raimondi et al., 2009]. Several studies have suggested that a mutation at residue 70 in the core protein of genotype $1 \mathrm{~b}$ isolates was associated with HCC development [Akuta et al., 2007; Fishman et al., 2009; Khaliq et al., 2011; El-Shamy et al., 2013]. In this respect, a possible role of mutation L91M has also been mentioned [Akuta et al., 2007; Khaliq et al., 2011]. The core protein with mutations at residues 70 and 91 has been shown to bind and activate protein kinase $\mathrm{R}$, which might cause carcinogenesis [Delhem et al., 2001]. Another study has shown that non-wildtype 70/91 pattern was significantly associated with cirrhosis development in patients with F0-F3 fibrosis [Nakamoto et al., 2010]. Moreover, it has been demonstrated that the mutation at codon 70 was associated with more advanced liver fibrosis stage in Taiwanese HCV genotype 1 patients [Hsu et al., 2011]. In this study, mutation at codon 70 in
HCV genotype 1b strains was significantly more frequent in patients with cirrhosis than in those without (56.3\% vs. $9.1 \%, P=0.018)$ and in HCC plus cirrhosis groups than without cirrhosis group (50.0\% vs. $9.1 \%, P=0.028$; Table V). This constituted one more line of evidence suggesting that a mutation at HCV core residue 70 may facilitate HCC development by accelerating fibrosis and/or cirrhosis.

To our knowledge, this is the first study that assessed the genetic variability of $\mathrm{HBV}$ and $\mathrm{HCV}$ isolates among Brazilian HCC patients. Further studies are necessary to determine whether given genotypes and mutations in the genomes of HBV and HCV might be used as biomarkers leading to improved early detection strategies and more effective therapies for patients with HBV- or HCV-related HCC.

\section{ACKNOWLEDGMENTS}

The authors thank Dr. Marcia T.B. Moraes for her valuable comments during preparation of the manuscript and the DNA Sequencing Platform PDTIS/ FIOCRUZ for performing nucleotide sequencing.

\section{REFERENCES}

Akuta N, Suzuki F, Kawamura Y, Yatsuji H, Sezaki H, Suzuki Y, Hosaka T, Kobayashi M, Kobayashi M, Arase Y, Ikeda K, Kumada H. 2007. Amino acid substitutions in the hepatitis C virus core region are the important predictor of hepatocarcinogenesis. Hepatology 46:1357-1364.

Araujo NM, Mello FC, Yoshida CF, Niel C, Gomes SA. 2004. High proportion of subgroup A' (genotype A) among Brazilian isolates of hepatitis B virus. Arch Virol 149:1383-1395.

Araujo NM, Araujo OC, Silva EM, Villela-Nogueira CA, Nabuco LC, Parana R, Bessone F, Gomes SA, Trepo C, Kay A. 2013. 
Identification of novel recombinants of hepatitis B virus genotypes $\mathrm{F}$ and $\mathrm{G}$ in human immunodeficiency virus-positive patients from Argentina and Brazil. J Gen Virol 94:150-158.

Arzumanyan A, Reis HM, Feitelson MA. 2013. Pathogenic mechanisms in HBV- and HCV-associated hepatocellular carcinoma. Nat Rev Cancer 13:123-135.

Asim M, Malik A, Sarma MP, Polipalli SK, Begum N, Ahmad I, Khan LA, Husain SA, Akhtar N, Husain S, Thayumanavan L, Singla R, Kar P. 2010. Hepatitis B virus BCP, precore/core, X gene mutations/genotypes and the risk of hepatocellular carcinoma in India. J Med Virol 82:1115-1125.

Bruno S, Crosignani A, Maisonneuve P, Rossi S, Silini E, Mondelli MU. 2007. Hepatitis $\mathrm{C}$ virus genotype $1 \mathrm{~b}$ as a major risk factor associated with hepatocellular carcinoma in patients with cirrhosis: A seventeen-year prospective cohort study. Hepatology 46:1350-1356.

Campiotto S, Pinho JR, Carrilho FJ, Da Silva LC, Souto FJ, Spinelli V, Pereira LM, Coelho HS, Silva AO, Fonseca JC, Rosa H, Lacet CM, Bernardini AP. 2005. Geographic distribution of hepatitis C virus genotypes in Brazil. Braz J Med Biol Res 38:41-49.

Carrilho FJ, Kikuchi L, Branco F, Goncalves CS, Mattos AA, Brazilian HCC Study Group. 2010. Clinical and epidemiological aspects of hepatocellular carcinoma in Brazil. Clinics 65:12851290.

Chan HL, Hui AY, Wong ML, Tse AM, Hung LC, Wong VW, Sung JJ. 2004. Genotype C hepatitis B virus infection is associated with an increased risk of hepatocellular carcinoma. Gut 53:1494-1498.

Chen CH, Eng HL, Lee CM, Kuo FY, Lu SN, Huang CM, Tung HD, Chen CL, Changchien CS. 2004. Correlations between hepatitis $\mathrm{B}$ virus genotype and cirrhotic or non-cirrhotic hepatoma. Hepatogastroenterology 51:552-555.

de Almeida AJ, Campos-de-Magalhaes M, de Melo Marcal, OP Brandao-Mello CE, Okawa MY, de Oliveira RV, do EspiritoSanto MP, Yoshida CF, Lampe E. 2004. Hepatitis C virusassociated thrombocytopenia: A controlled prospective, virological study. Ann Hematol 83:434-440.

Delhem N, Sabile A, Gajardo R, Podevin P, Abadie A, Blaton MA, Kremsdorf D, Beretta L, Brechot C. 2001. Activation of the interferon-inducible protein kinase PKR by hepatocellular carcinoma derived-hepatitis $\mathrm{C}$ virus core protein. Oncogene 20:5836-5845.

El-Serag HB. 2012. Epidemiology of viral hepatitis and hepatocellular carcinoma. Gastroenterology 142:1264-1273.e1.

El-Shamy A, Shindo M, Shoji I, Deng L, Okuno T, Hotta H. 2013. Polymorphisms of the core, NS3 and NS5A proteins of hepatitis C 1 virus genotype $1 \mathrm{~b}$ associate with development of hepatocellular carcinoma. Hepatology 58:555-563.

Ferlay J, Shin HR, Bray F, Forman D, Mathers C, Parkin DM. 2008. GLOBOCAN v2.0, Cancer Incidence and Mortality Worldwide: IARC Cancer Base No. 10 [Internet]. Lyon, France: International Agency for Research on Cancer. 2010. Available from: http://globocan.iarc.fr, accessed in June 2013.

Fishman SL, Factor SH, Balestrieri C, Fan X, Dibisceglie AM, Desai SM, Benson G, Branch AD. 2009. Mutations in the hepatitis C virus core gene are associated with advanced liver disease and hepatocellular carcinoma. Clin Cancer Res 15:3205-3213.

Hsu SJ, Hsu CS, Liu CH, Liu CJ, Chen CL, Chen PJ, Chen DS, Kao JH. 2011. HCV core gene polymorphisms correlate with liver fibrosis but not sustained virological response in patients with genotype 1 infection. Antivir Ther 16:227-235.

Idrees M, Rafique S, Rehman I, Akbar H, Yousaf MZ, Butt S, Awan Z, Manzoor S, Akram M, Aftab M, Khubaib B, Riazuddin S. 2009. Hepatitis $\mathrm{C}$ virus genotype $3 \mathrm{a}$ infection and hepatocellular carcinoma: Pakistan experience. World J Gastroenterol 15:5080-5085.

Kao JH, Chen PJ, Lai MY, Chen DS. 2002. Genotypes and clinical phenotypes of hepatitis B virus in patients with chronic hepatitis B virus infection. J Clin Microbiol 40:1207-1209.

Kao JH, Liu CJ, Jow GM, Chen PJ, Chen DS, Chen BF. 2012. Fine mapping of hepatitis $\mathrm{B}$ virus pre-S deletion and its association with hepatocellular carcinoma. Liver Int 32:1373-1381.

Kew MC, Kramvis A, Yu MC, Arakawa K, Hodkinson J. 2005. Increased hepatocarcinogenic potential of hepatitis B virus genotype A in Bantu-speaking sub-Saharan Africans. J Med Virol 75:513-521.

Khaliq S, Jahan S, Pervaiz A. 2011. Sequence variability of HCV core region: Important predictors of HCV induced pathogenesis and viral production. Infect Genet Evol 11:543-556.
Kitab B, Essaid El, Feydi A, Afifi R, Trepo C, Benazzouz M, Essamri W, Zoulim F, Chemin I, Alj HS, Ezzikouri S, Benjelloun S. 2012. Variability in the precore and core promoter regions of HBV strains in Morocco: Characterization and impact on liver disease progression. PloS ONE 7:e42891.

Kobayashi M, Akuta N, Suzuki F, Hosaka T, Sezaki H, Kobayashi M, Suzuki Y, Arase Y, Ikeda K, Watahiki S, Mineta R, Iwasaki S, Miyakawa Y, Kumada H. 2010. Influence of amino-acid polymorphism in the core protein on progression of liver disease in patients infected with hepatitis $\mathrm{C}$ virus genotype $1 \mathrm{~b}$. J Med Virol 82:41-48.

Kramvis A, Kew MC, Bukofzer S. 1998. Hepatitis B virus precore mutants in serum and liver of Southern African Blacks with hepatocellular carcinoma. J Hepatol 28:132-141.

Liu CJ, Chen BF, Chen PJ, Lai MY, Huang WL, Kao JH, Chen DS. 2006. Role of hepatitis B viral load and basal core promoter mutation in hepatocellular carcinoma in hepatitis B carriers. J Infect Dis 193:1258-1265.

Livingston SE, Simonetti JP, McMahon BJ, Bulkow LR, Hurlburt KJ, Homan CE, Snowball MM, Cagle HH, Williams JL, Chulanov VP. 2007. Hepatitis B virus genotypes in Alaska native people with hepatocellular carcinoma: Preponderance of genotype F. J Infect Dis 195:5-11.

Martins RM, Vanderborght BO, Yoshida CF. 1998. Hepatitis C virus genotypes among blood donors from different regions of Brazil. Mem Inst Oswaldo Cruz 93:299-300.

Mello FC, Souto FJ, Nabuco LC, Villela-Nogueira CA, Coelho HS, Franz HC, Saraiva JC, Virgolino HA, Motta-Castro AR, Melo MM, Martins RM, Gomes SA. 2007. Hepatitis B virus genotypes circulating in Brazil: Molecular characterization of genotype $\mathrm{F}$ isolates. BMC Microbiol 7:103.

Motta-Castro AR, Martins RM, Araujo NM, Niel C, Facholi GB, Lago BV, Mello FC, Gomes SA. 2008. Molecular epidemiology of hepatitis B virus in an isolated Afro-Brazilian community. Arch Virol 153:2197-2205.

Nakamoto S, Imazeki F, Fukai K, Fujiwara K, Arai M, Kanda T, Yonemitsu Y, Yokosuka O. 2010. Association between mutations in the core region of hepatitis $\mathrm{C}$ virus genotype 1 and hepatocellular carcinoma development. J Hepatol 52:72-78.

Ohno O, Mizokami M, Wu RR, Saleh MG, Ohba K, Orito E, Mukaide M, Williams R, Lau JY. 1997. New hepatitis C virus (HCV) genotyping system that allows for identification of HCV genotypes $1 \mathrm{a}, 1 \mathrm{~b}, 2 \mathrm{a}, 2 \mathrm{~b}, 3 \mathrm{a}, 3 \mathrm{~b}, 4,5 \mathrm{a}$, and 6a. J Clin Microbiol 35:201-207.

Oliveira ML, Bastos FI, Sabino RR, Paetzold U, Schreier E, Pauli G, Yoshida CF. 1999. Distribution of HCV genotypes among different exposure categories in Brazil. Braz J Med Biol Res 32:279-282.

Perz JF, Armstrong GL, Farrington LA, Hutin YJ, Bell BP. 2006. The contributions of hepatitis $\mathrm{B}$ virus and hepatitis $\mathrm{C}$ virus infections to cirrhosis and primary liver cancer worldwide. J Hepatol 45:529-538.

Qu L, Kuai X, Liu T, Chen T, Ni Z, Shen X. 2013. Pre-S deletion and complex mutations of hepatitis $\mathrm{B}$ virus related to young age hepatocellular carcinoma in Qidong, China. PloS ONE 8:e59583.

Raimondi S, Bruno S, Mondelli MU, Maisonneuve P. 2009. Hepatitis $\mathrm{C}$ virus genotype $1 \mathrm{~b}$ as a risk factor for hepatocellular carcinoma development: A meta-analysis. J Hepatol 50:11421154.

Sanchez-Tapias JM, Costa J, Mas A, Bruguera M, Rodes J. 2002. Influence of hepatitis B virus genotype on the long-term outcome of chronic hepatitis B in Western patients. Gastroenterology 123:1848-1856.

Tamura K, Peterson D, Peterson N, Stecher G, Nei M, Kumar S. 2011. MEGA5: Molecular evolutionary genetics analysis using maximum likelihood, evolutionary distance, and maximum parsimony methods. Mol Biol Evol 28:2731-2739.

Tsai WL, Chung RT. 2010. Viral hepatocarcinogenesis. Oncogene 29:2309-2324.

Venook AP, Papandreou C, Furuse J, de Guevara LL. 2010. The incidence and epidemiology of hepatocellular carcinoma: A global and regional perspective. Oncologist 15:5-13.

Yang HI, Yeh SH, Chen PJ, Iloeje UH, Jen CL, Su J, Wang LY, Lu SN, You SL, Chen DS, Liaw YF, Chen CJ, Group R-HS. 2008. Associations between hepatitis $\mathrm{B}$ virus genotype and mutants and the risk of hepatocellular carcinoma. J Natl Cancer Inst 100:1134-1143. 